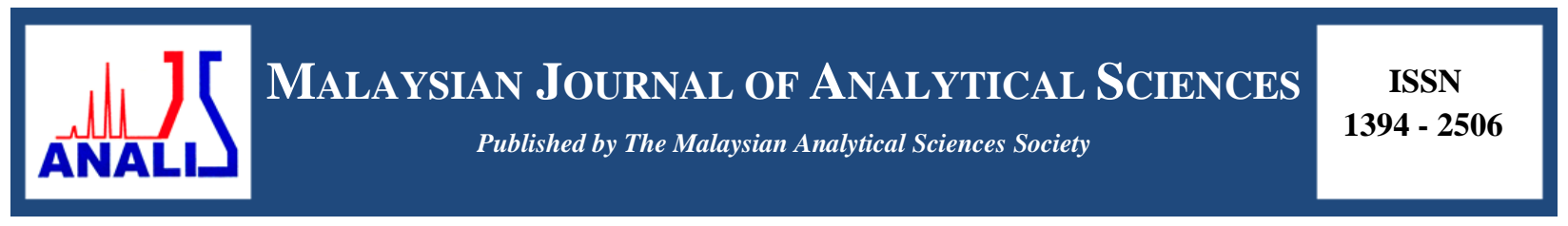

\title{
MECHANICAL PROPERTIES OF BIOPLASTIC FROM JACKFRUIT SEED FLOUR AND POLYPROPYLENE
}

\author{
(Sifat Mekanikal Bioplastik daripada Tepung Biji Nangka dan Polipropelina) \\ Fairuzdzah Ahmad Lothfy*, Asiah Mohd Nor, Syamsyir Akmal Senawi, Nur Sha'adah Zainuddin, \\ Ermadasila Mohmad, Nur Aina Shuhada Norzeri, Nur Yasmin Sahira Saifful Bahri, \\ Puteri Elyana Natasa Mohmad Azmi, Aliya Nuharissa Kamaruzaman \\ Faculty of Applied Sciences, \\ Universiti Teknologi MARA Pahang, 26400 Bandar Tun Razak Jengka, Pahang, Malaysia \\ *Corresponding author: fairuzdzah@pahang.uitm.edu.my
}

Received: 4 December 2016; Accepted: 1 December 2017

\begin{abstract}
In this study, the bioplastic was successfully fabricated from jackfruit seed flour/polypropylene blend. Nowadays, the plastic used are originally from petroleum, in which is limited resources and non-degradable polymer that causes environmental problem. The jackfruit (Artocarpus heterophyllus) has been commercially produced in the farming industry. Approximately 8 to $15 \%$ of jackfruit are mostly thrown after consumption. Thus it can be used as the value added product development for future demand. In this study, the jackfruit seeds flour was plasticized by using glycerol, and blended with different ratios of polypropylene. The mechanical properties such as tensile strength, strain at break, flexibility and water absorption of fabricated bioplastic were investigated. The tensile strength and strain at break decreased with increasing of jackfruit seed flour content, while Young's Modulus increased with the jackfruit seed flour content increased. Addition of polypropylene demonstrated higher water resistant ability. The jackfruit seed can be a new resource of bioplastic that could be preserved as a petrochemical resource and reduces the environmental impact.
\end{abstract}

Keyword: bioplastic, jackfruit seed, mechanical properties, polypropylene, water absorption

Abstrak
Dalam kajian ini, bioplastik berjaya dihasilkan dari campuran tepung biji nangka/polipropilena. Kini, plastik yang digunakan berasal daripada petroleum, di mana sumber yang terhad dan polimer yang tidak boleh degradasi yang menyebabkan masalah kepada alam sekitar. Buah nangka (Artocarpus heterophyllus) telah dihasilkan secara komersil dalam industri pertanian. Kirakira 8 hingga 15\% daripada nangka dibuang selepas penggunaan. Oleh itu, ia boleh digunakan sebagai nilai tambah produk untuk permintaan masa depan. Dalam kajian ini, tepung biji nangka telah diplastikkan dengan menggunakan gliserol, dan dicampur dengan polipropilena dengan nisbah yang berlainan. Sifat-sifat mekanik seperti kekuatan tegangan, ketegangan pada rehat, fleksibiliti dan penyerapan air bioplastik dikaji. Kekuatan tegangan dan ketegangan pada rehat menurun dengan peningkatan kandungan tepung biji nangka, sementara Modulus Young meningkat dengan kandungan tepung biji nangka meningkat. Penambahan polipropilena menunjukkan keupayaan tahan air yang lebih tinggi. Biji nangka dapat menjadi sumber bioplastik baru yang dapat dipelihara sebagai sumber petrokimia dan mengurangkan kesan kepada persekitaran.

Kata kunci: bioplastik, biji nangka, sifat mekanik, polipropilena, penyerapan air 


\section{Fairuzdzah et al: MECHANICAL PROPERTIES OF BIOPLASTIC FROM JACKFRUIT SEED FLOUR AND POLYPROPYLENE}

\section{Introduction}

Bioplastics can be fabricated by whole or some parts from renewable biomass sources such as sugarcane and corn, or from microbe such as yeast [1]. According to European Bioplastics, bioplastic is defined if the plastic made of bio-based, biodegradable, or features both properties [2]. The Future of Bioplastics for Packaging to 2020 examines the global market for bioplastic packaging and concludes with an assessment of the key challenges and opportunities that face suppliers in the wider commercialization of bioplastics for food and drink packaging [3]. Nowadays, bioplastics have become a necessity in many industrial applications such as food packaging, agriculture and horticulture, composting bags, and hygiene. With increasing demand for global plastic consumption in many branches, a lot of research is being dedicated toward exploring green materials and new ways to produce bioplastic [1].

The greater amount used for synthetic packaging films has led to a serious ecological problems due to their total non-biodegradability [4]. Commonly, synthetic thermoplastics are blended with starch or other biopolymer to enhance the potential biodegradability of polyolefin [5]. Polypropylene (PP), a synthetic polymer is an economical material that provides excellent physical, mechanical, thermal, and chemical properties that are not found in any other thermoplastic polymer [6]. According to Obasi et al., PP has good properties such as high strength and flexibility, good process ability, excellent resistance to acids, alcohols, bases and esters and dimensional stability [7]. Even so, PP wastes persist for many years after disposal and might be causing environmental hazards. The introduction of biodegradable polymers or natural fillers such as starch in PP based materials formulation might be considered as a credible alternative in the development of eco-friendly material and overcome non-degradability issue [7]. Obasi et al. concluded that the blend of PP/cassava starch increases the starch content, increases the surface area available for the microbial agents to 'attack and eat' the starch-PP blend, and increases the biodegradation rate [8]. Therefore, researchers have studied the incorporation of biodegradable polymers, such as jackfruit seed into the PP, which is justified by the presence of hydrolysable groups in the natural polymer that are able to induce the biodegradation of the PP and demonstrates significant potential in the bioplastic field.

Artocarpus heterophyllus Lam., or jackfruit, is a non-seasonal plant with many benefits [9]. Jackfruit (Artocarpus heterophyllus L.) belongs to the family Moraceae and contributes to the value of agricultural production in Malaysia. According to Agrofood Statistics 2014, the production of jackfruit in Malaysia increases every year and achieves for 33,788 tonne at 2014 [10]. About 8 to $15 \%$ of the total fruit Jackfruit weight were seeds and it's have fairly high carbohydrate and protein contents [11]. Starch is a natural carbohydrate storage material accumulated by green plants in the form of granules. It is composed of linear polysaccharide molecules (amylose) and branched molecules (amylopectin) that are attractive raw material for use as barriers in packing materials [12]. The jackfruit seeds starch compositions are moisture $13.0 \%$, fat $(0.64 \%)$, protein $(0.32 \%)$, ash $(0.22 \%)$, and amylose $(28.1 \%)$ [12]. Jackfruit's seeds comprise $90 \%$ of starch content [13]. Jackfruit seeds starch consists of two macromolecules: amylose (20-30\%) and amylopectin (70-80\%), which are associated with each other by hydrogen bonds [14]. Menzel et al. found that the increased amylose content and structural changes in amylopectin enhances film-forming behavior and improves barrier and tensile properties in starch films [15].

\section{Materials and Methods}

Jackfruits (Artocarpus heterophyllus) were chosen based on uniformity and visually free from defects were purchased at local market. At first, ripened fruit de-husked and their seeds were removed, cleaned, and rinsed thoroughly with sterile distilled water. The brown seed coats were removed. The fleshy white cotyledons were collected by scrubbing through water. Subsequently, the cleaned jackfruit seeds were chopped into small dimensions. Then, the seeds were dried by air circulation. By using Rotor Beater Mill SR 200, the chopped seeds were milled into flour. Then, the flour was sieved (100 mesh) and collected. Firstly, $20 \%$ of water was mixed into the jackfruit seed powder. Glycerol and hydrochloric acid $0.1 \mathrm{M}$ were gradually added into the mixture. After that, the mixture was heated and stirred until almost boiling point. Sodium hydroxide $0.1 \mathrm{M}$ were added and the mixture was poured into petri dish. The mixture was dried at room temperature. Subsequently, the sample was crushed by using crusher machine. After that, the crushed sample and polypropylene was blended into rheomixer at $170{ }^{\circ} \mathrm{C}$ by ratio 9:1, 7:3, and 5:5. The blended sample was crushed again and poured into mold by using hot press machine at $170{ }^{\circ} \mathrm{C}$ for 5 minutes and cold press at $0{ }^{\circ} \mathrm{C}$. 
The mechanical properties of the fabricated bioplastic were determined from tensile stress, maximum strain, and Young's modulus by using Testometric Materials Testing machine. To obtain these values, $15 \mathrm{~mm}$ wide section and initial length $25 \mathrm{~mm}$ of the bioplastic sample was cut and attached to Testometric Materials Testing machine. Each end of the samples was clamped and the upper clamp of the sample was pulled up until it was broken. The information such as the tensile stress, maximum strain, and Young's modulus were measured.

The bioplastic samples were cut into $1 \mathrm{~cm} \mathrm{x} 1 \mathrm{~cm}$ for water absorption test. Each sample was weighed prior to immersion in distilled water. Subsequently, the surfaces were wiped until it became dry, re-weighed, and calculated for the percentage of water absorption. Results were recorded every 5 days for 20 days. Three samples were used for each formulation and the average was determined. The percentage of water absorption, $\% M_{t}$ was calculated according to equation 1 below:

$$
\% M_{t}=\frac{w_{s}-w_{0}}{w_{o}} \times 100
$$

whereas, $\mathrm{M}_{\mathrm{t}}=$ total water absorption, $\mathrm{W}_{\mathrm{s}}=$ weight of sample after immersion in water and $\mathrm{W}_{\mathrm{o}}=$ original weight of sample before immersion.

\section{Results and Discussion}

Mechanical properties of the fabricated bioplastic were determined by calculating the maximum strain, tensile stress and Young's modulus values. Fundamentally, biological polymers show good biocompatibility, but their mechanical properties are often poor. Hence, the jackfruit seeds/ polypropylene blends in order to improve the mechanical properties of the fabricated bioplastic.

Figure 1 shows the variation of the tensile strength and strain percentage with the blend ratio of jackfruit seeds/PP. This figure showed that by increasing the amount of jackfruit seeds in the fabricated bioplastic, the tensile strength and the strain percentage of bioplastic decreased accordingly. It was clear that the tensile strength and elongation at break of jackfruit seeds/PP blends decreased from $12.07 \mathrm{M}$ Pa to $8.16 \mathrm{M} \mathrm{Pa}$ and $10.3 \%$ to $7.03 \%$ respectively. Gupta (2014) studied that the tensile strength is $30.23 \mathrm{MPa}$ [16]. From the results, it showed that more than 50\% of the tensile strength and percentage of strain decreased after adding $50 \%$ of jackfruit seed into the blend. It is possible that the reduction of tensile strength and strain percentage is the amorphous nature of the jackfruit seed which has increased the brittleness. Similarly, the same observation occurred in the previous literatures [17, 18]. Shafiq et al. also found that the tensile strength and strain percentage decrease with increasing the percentage of corn starch in PVA/corn starch film [18]. The research concludes that the amorphous nature of starch increase the brittleness lead to decreasing of tensile strength and stain percentage. Research conducted by Parvin et al. the tensile strength of PVA/ starch decreased due to increasing of crystallization of the blend. The researcher observed the crystallization by using the micrograph analysis [17]. Rosa et al. observes the same behavior for high density polyethylene/polypropylene (HDPE/PP) starch blends [12]. These results are similarly shown in the previous work by Toh Wen et al. which finds the same trend of the graph for the study on poly vinyl alcohol)/sago pith waste (SPW) [5]. The tensile strength and elongation at break decreases with increasing SPW content and conclude the decreasing strength with increasing starch content contributed to the poor interfacial adhesion of the two components [5].

Figure 2 shows that Young's modulus increased from $1901.12 \mathrm{M} \mathrm{Pa}$ at $50 \mathrm{wt} \%, 2207.68 \mathrm{M} \mathrm{Pa}$ at $70 \mathrm{wt} \%$, and $2598.38 \mathrm{M} \mathrm{Pa}$ at $90 \mathrm{wt} \%$. Young's modulus increased because of the stiffening effect of the granules. The hydrogen bonding in starch of jackfruit seed gave higher modulus than that of a semi-crystalline polymer like PP, with no hydrogen bonding [7]. A similar result is shown in previous work by Toh Wen et al. where the incorporation of SPW fillers into PVA has led to an increase in the modulus of the composites. This condition is due to that starch granules are stiffer than the PVA matrix in which they are dispersed [5]. Another of probability for the high modulus was due to the fact that jack fruit seed granules were not melting and retain their shape as rigid filler during processing. As the jackfruit seed contents increased, particles were crowded and reduced the particle-matrix interaction. The fabricated bioplastic became more rigid and stiffer with increasing percentage of jackfruit seed. 
Fairuzdzah et al: MECHANICAL PROPERTIES OF BIOPLASTIC FROM JACKFRUIT SEED FLOUR AND POLYPROPYLENE

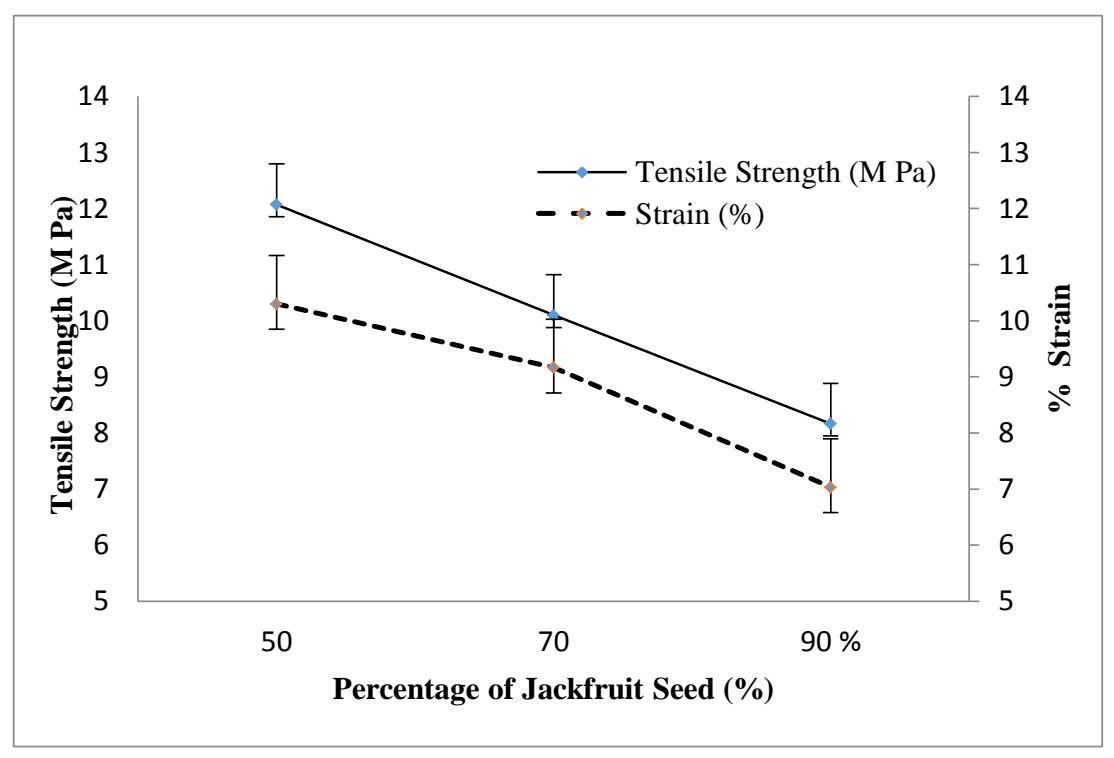

Figure 1. Variation of the tensile strength and percentage of strain with the percentage of jackfruit seeds in the blend

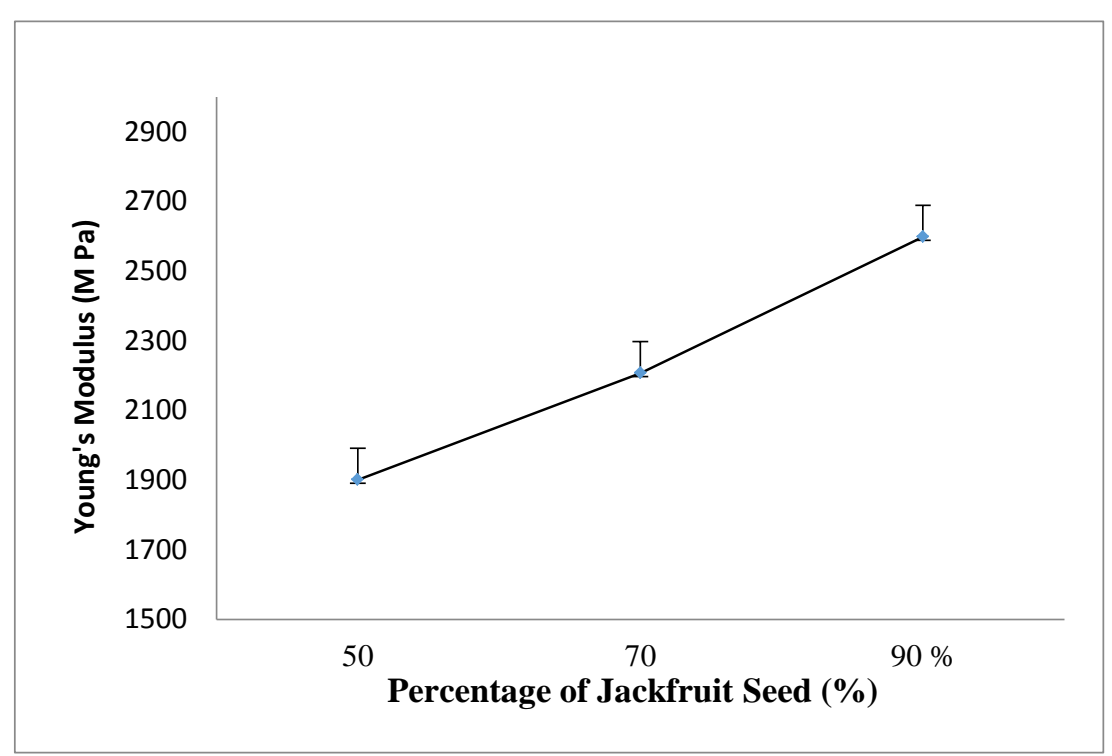

Figure 2. Variation of the Young's Modulus with the percentage of jackfruit seeds in the blend

Figure 3 shows the percentage of water absorbed by jackfruit seeds/PP blends bioplastic as a function of time. Water absorption increased with increasing immersion time and jackfruit seed content. This observation was due to the hydrophilic nature of jackfruit seed whereas have $25 \%$ to $40 \%$ of the quantity of starch was responsible for the water absorption in the blends. Hence, at higher jackfruit seed content, a higher amount of water was being absorbed. The increment of water absorption for jackfruit seed/PP blends was about $4.76 \%, 13.33 \%$ and $23.08 \%$ at $50 \mathrm{wt} . \%, 70 \mathrm{wt} . \%$ and $90 \mathrm{wt} . \%$ of the jackfruit seed contents. The higher percentage water absorption increment to 
90 wt. \% was due to the leaching away of jackfruit seed particles from the samples at high content with increasing time. By increasing the jackfruit seed content in the blends, it reduced interfacial compatibility of hydrophilic particles with hydrophobic polymer matrices (PP). Thereby, the blends would cause weaker adhesion between the composition and subsequently increase dispersion of water within the blends and enhance the moisture uptake rate [19].

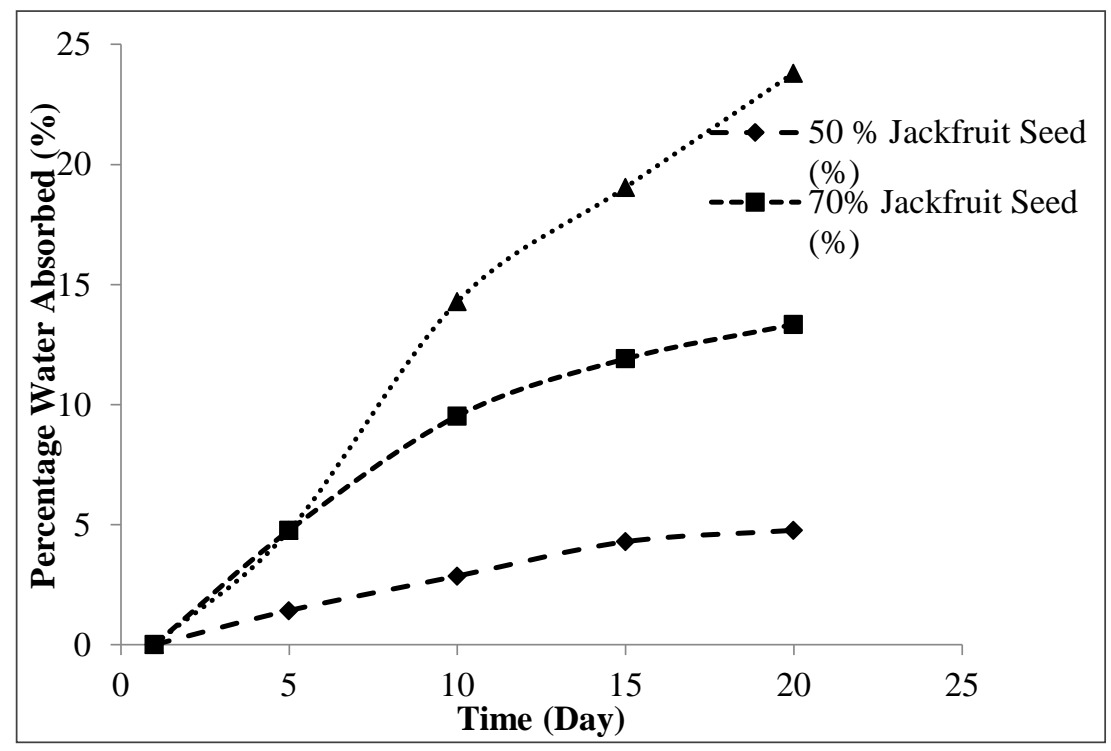

Figure 3. Percentage water absorption of jackfruit seeds/PP blend bioplastic

\section{Conclusion}

As conclusion, the results of mechanical strength show that all types' compositions in the blend have suitability properties for fabricating the bioplastic. The higher composition of jackfruit seeds in the blend will produce the bioplastic with the lower water resistance because the higher absorption rate. Although, all types composition show that the percentage of water absorption less than $25 \%$. Hence, the suitability for choosing the composition to fabricate the bioplastic depend on their own application.

\section{Acknowledgement}

Authors acknowledge the financial support for this research from the Universiti Teknologi MARA Pahang.

\section{References}

1. Ashter, S. A. (2016). New developments introduction to bioplastics engineering. Oxford: William Andrew Publishing, New York: pp. 251-274.

2. Gill, M. (2014). Bioplastic: A better alternative to plastics. International Journal of Research in Applied, Natural and Social Sciences, 2(8): 115-120.

3. The Future of Bioplastics for Packaging to 2020. (2015). United Kingdom: Smithers Pira.

4. Siracusa, V., Rocculi, P., Romani, S. and Dalla Rosa, M. (2008). Biodegradable polymers for food packaging: A review. Trends in Food Science \& Technology, 19(12): 634-643.

5. Toh Wen, Y., Lai Jau, C. and Wan A. W. A. R. (2011). Mechanical and water absorption properties of poly(vinyl alcohol)/sago pith waste biocomposites. Journal of Composite Materials, 45(11): 1201-1207.

6. Rodriguez-Llamazares, S. (2013). Polypropylene/starch blends: Study of thermal and morphological properties. Journal of the Chilean Chemical Society, 58(1): 1643-1646. 
7. Obasi, H. C. and Igwe, I. O. (2012). Cassava starch-mixed polypropylene bidegradable polymer: Preparation, characterization, and effect biodegradable products on growth of plants. International Journal of Science and Research, 3(7): 802-807.

8. Obasi, H., Onuoha, F., Eze, I., Nwanonenyi, S., Arukalam, I. and Uzoma, P. (2013). Effect of soil burial on properties of polypropylene (PP)/plasticized potato starch (PPS) blends. The International Journal of Engineering and Science, 2(8): 14-18.

9. Ismail, B. K. N. (2013). Consumer preference for jackfruit varieties in Malaysia. Journal of Agribusiness Marketing, 6: 37-51.

10. Ministry of Agriculture and Agro-Based Industry (2015). Agrofood Statistics 2014: Information Management and Statistics Section, Policy and Strategic Planning Division: pp. 39.

11. Tran, P. L., Nguyen, D. H. D., Do, V. H., Kim, Y.-L., Park, S., Yoo, S.-H. and Kim, Y.-R. (2015). Physicochemical properties of native and partially gelatinized high-amylose jackfruit (Artocarpus heterophyllus Lam.) seed starch. LWT - Food Science and Technology, 62(2): 1091-1098.

12. Rosa, D. S., Guedes, C. G. F. and Carvalho, C. L. (2007). Processing and thermal, mechanical and morphological characterization of post-consumer polyolefins/thermoplastic starch blends. Journal of Materials Science, 42(2): 551-557.

13. Madruga, M. S., de Albuquerque, F. S. M., Silva, I. R. A., do Amaral, D. S., Magnani, M. and Queiroga Neto, V. (2014). Chemical, morphological and functional properties of Brazilian jackfruit (Artocarpus heterophyllus L.) seeds starch. Food Chemistry, 143: 440-445.

14. Bobbio F. O., el Dash, A. A., Bobbio P. A. and Rodrigues L. R. (1978). Isolation and characterization of the physiochemical properties of the starch of jackfruit seeds (Artocarpus heterophyllus). The American Association of Cereal Chemists, 55(4): 505-511.

15. Menzel, C., Andersson, M., Andersson, R., Vazquez-Gutierrez, J. L., Daniel, G., Langton, M. and Koch, K. (2015). Improved material properties of solution-cast starch films: Effect of varying amylopectin structure and amylose content of starch from genetically modified potatoes. Carbohydrate Polymers, 130: 388-397.

16. Gupta A.P. and Alam, A. (2014). Study of flexural, tensile, impact properties and morphology of potato starch/polypropylene blends. International Journal of Advanced Research, 2(11): 599-604.

17. Shafik S. S., Majeed, K. J. and Kamil, M. I. (2014). Preparation of PVA/corn starch blend films and studying the influence of gamma irradiation on mechanical properties. International Journal of Materials Science and Applications, 3(2): 25-28.

18. Parvin, F., Rahman, M. A., Islam, J. M. M., Khan, M. A. and Saadat, A. H. M. (2010). Preparation and characterization of starch/PVA blend for biodegradable packaging material. Advanced Materials Research, 123-125: 351-354.

19. Visakh, P. M., L. Y. (2016). Starch-based blends, composites and nanocomposites. United Kingdom: Royal Society of Chemistry : pp 85-86. 